\title{
Draft Implementation Plan for the \\ Hawaii Geothermal Project Environmental Impact Statement
}

Prepared by

The United States Department of Energy

Conservation and Renewable Energy

Washington, D.C.

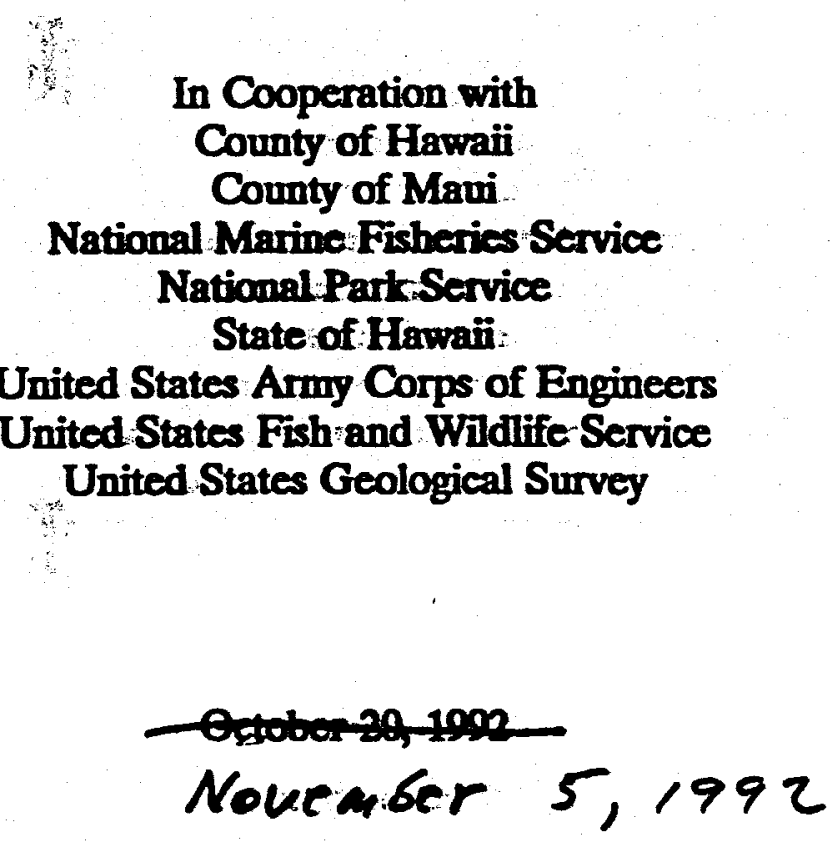




\section{DISCLAIMER}

This report was prepared as an account of work sponsored by an agency of the United States Government. Neither the United States Government nor any agency Thereof, nor any of their employees, makes any warranty, express or implied, or assumes any legal liability or responsibility for the accuracy, completeness, or usefulness of any information, apparatus, product, or process disclosed, or represents that its use would not infringe privately owned rights. Reference herein to any specific commercial product, process, or service by trade name, trademark, manufacturer, or otherwise does not necessarily constitute or imply its endorsement, recommendation, or favoring by the United States Government or any agency thereof. The views and opinions of authors expressed herein do not necessarily state or reflect those of the United States Government or any agency thereof. 


\section{DISCLAIMER}

Portions of this document may be illegible in electronic image products. Images are produced from the best available original document. 
overland and submarine power transmission routes; sites reasonably suited to support project facilities in a safe and environmentally acceptable manner; and non-power generating alternatives, such as conservation and demand-side management.

\subsection{PURPOSE OF THE EIS IMPLEMENTATION PLAN}

DOE has prepared this draft Implementation Plan (IP) for two purposes: (1) to provide internal guidance for the EIS preparation, and (2) to record issues identified during the scoping process. To serve these purposes, this IP has been prepared in accordance with DOE NEPA Regulations (57 Fed. Regist. 15122, April public of DOE's approach in preparing the EIS and to document the results of the public scoping process. The IP is a "living document" in that it may be revised as needed throughout the preparation of the EIS to provide-updated information regarding major changes in scope, methodology, or work plan. The draft IP will be given broad distribution by including individuak and organizations on a mailing list compiled by DOE to provide information about the preparation of the EIS. In dddition, the draft:IP will be placed in all BOER EadingRooms (sce:Attachment 2 to 7)

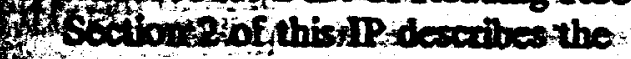
fotinentof altematives Section 3 discusses

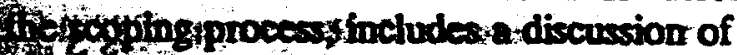
the-major issues identified through public rooping, andias-appropriate states how these issues:will be addressed in the EIS. 4 onsultations with agencies, preparers of the II significantu EIS milestones, and related 4h forimental documentation are described of is 1992) (10 CFR 1021). The IP has been made available at this time to inform the it. Secting 4 Section 5 contains references.

summary of agency scoping comments, a preliminary outline for the EIS, a glossary of terms used in the IP, a list of acronyms and abbreviations, copies of the Advance Notice of Intent and Notice of Intent, and the contractor diselosure statements. A working draft IP was prepared by DOE and reviewed with cooperating agencies (see Section 1.5) in July and August 1992. Comments by these agencies (Appendix B) are addressed in this draft IP.

\section{BACKGROUND OF HAWAII GEOTHERMAL PROJECT}

\subsection{Purpose and Neod for HGP}

The purpose of the HGP is to develop Hawaii's indigenous geothermal resource for the production of electricity. The State of Hawaii has declared in its 1990 proposal to


Ptarrand its 1991 State FunctionaliEnergy Plan that geothermal energy is needidt to help reduce the State's heavy dependence on imported oil Currently, the Strater of Hawaii use petroleum for approcinimety $90 \%$ of its energy, the highest percentage? usage of all 50 states.

\section{Description of HGP Ptimestrand 2}

The HGP is the culmination ofiresearch and development efforts beguithtint plitid-



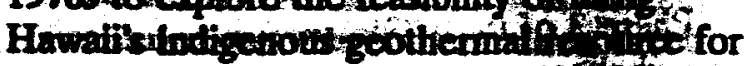

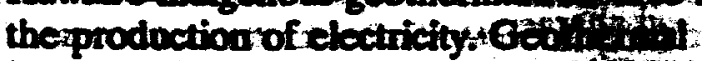

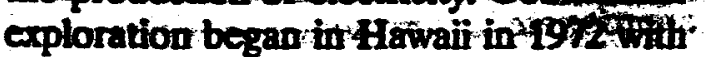
funding from the National Sciencers: Foundation (NSF). A high-potential : geothermal resource site was identified on the east rift of the Kilauea volcanoron the Bigissland:Subsequent exploratory ditilling (also:funded by NSF) between December 1975-and April 1976 resulted in a productive geothermad well at a depth of approvinately

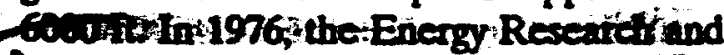

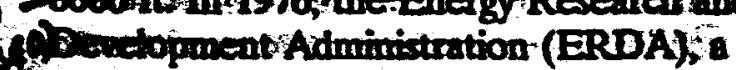




1
2
3
4
5
6
7
8
9
10
11
12
13
14
15 pen 400$)$
16
17

predecessor to DOE, funded the testing of the geothermal well, which was designated as the HGP-A well. In 1979, DOE funded the development of a 3-MW demonstration power plant at the HGP-A site. In 1986, the HGP-A facilities were transferred by DOE to the State of Hawaii to be used for further research. The State has referred to this early exploration and testing of the Big Island geothermal resource as Phase 1 of the HGP.

DOE also provided funds for the Hawaii Deep Water Cable Program (HDWC), which was initiated in 1981 and completed in 1991. The goal of the HDWC was to determine the technical andeoenomion feasibility of constructing and operating a directed in 1991 (House Resolution 1281) that ". . the Secretary of Energy shall use such sums as are necessary from amounts previously provided to the State of Hawaii for geothermal resource verification and characterization to conduct the necessary environmental assessments and/or environmental impact statement (EIS) for the geothermal initiative to proceed." In addition, the U.S. District Court of Hawaii. in litigation filed by several environmental groups (Civil No. 90-00407, June 25, 1991). ruled that the federal government must prepare an EIS for Phases 3 and 4 of the HGP before any further disbursement of federal funds was made to the State for the HGP.

\subsubsection{DOE Decision}

The decision being considered by DOE in its Record of Decision is whether or not to partially fund Phase 3 of the:HGP, as defined by the State in its 1990 proposal to Congress; using any funds remititinf from: the S5 million Congressional ippiopriation for Phase 3 after EIS expendifure-The funding for Phase 4 is currentif oncertain.

The EIS will evaluate the ectivities to be conducted during both Phases 3 and 4 of the HGP as required by Congressional : directive and U.S. District CotirteffHawaii ruling: However, the DOEdectsionawill be rendered only with regand to thest disbursement of federal fundsto 0 itist thte to

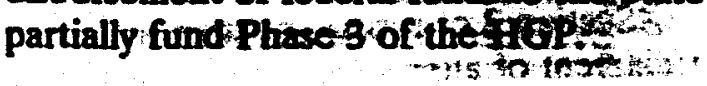

\subsubsection{Description of HGPPMESAS 3 and 4}

The State of Hawaii considers the unknown extent of its geothermal resource as one of the primary obstacles to private investment and commercial development in geothermalenergy productione'State and private industry experts estimate that at least 25 commercial-scale exploratory weths would need to be diriled to verify the geverating potential of the resource (these firls would 
in turn be used in Phase 4). To that end, Phase 3 activities would include well drilling, logging of cores from holes, measuring temperatures, collecting and analyzing geothermal fluid samples, and making downhole geophysical and geochemical measurements. Information on the feasible locations for Phase 3 activity and details regarding the methods of analyses will be obtained from various sources including the U.S. Geological Survey (USGS), University, of Hawaii. DOE and developers. S fatr of Hacue

Forecasts based on resource (per sow-s 660) characterization to date indicate that between 10 and 20 separate geothermal power plants of 25 to $50 \mathrm{MW}$ each could be developed. The actual number of plants would depend on the extent of the resource defined in Phase 3. Because the exact location of plants would not be known until Phase 3 was completed, the EIS will rely on best available data and information to encompass impacts at development sites. Further NEPA documentation may be required for specific projects and permits identified in the future. Based on the

physical characteristics of the resource and contemporary geothermal energy development practice, the State estimated that about 125 production wells and 30 \& injection wells may be needed to produce 7 o $0 . M W$. The plants most likety would be 1 connected by a network of roads, piping, and

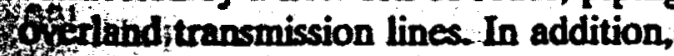
14. 19rid and underwater transmission lines th 3 tujuldibe constructed to If 1 powato Oahuand other islands


13ition of the transmission cable system. W Fot purposes of the:EIS analysis, a 1) ypul geothermal power plant may be 7. fly lecribed as consisting of a moderate 7) (-30 MW) single-lash; condensing cycle 17itinosoupled to a generator.Geothermal 14. In would pass from the wellhead through 3) introgand a demister, then to the whotem would allow complete to 5 turbine directly to the.

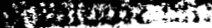

condenser. A two-stage steam ejector would remove gases from the direct-contact type condenser. Non-condensable gases including hydrogen sulfide $\left(\mathrm{H}_{2} \mathrm{~S}\right)$ would be compressed, mixed with other spent geothermal fluids (brine and steam condensate), and then injected by surface pumps into the general vicinity of the geothermal reservoir. Steam condensate from the condenser would be cooled by a forced draft cooling tower. Power plant. transmission line, and submarine cable technologies will be further defined as the EIS progresses using information from various sources including the Hawaiian Electric Company (HECO), the State of Hawaii, USGS, the University of Hawaii. Puna Geothermal Venture, True Geothermal Energy Company, Mission Energy Company, Mid-Pacific Geothermal, Inc. Campbell Estate, and DOE. In addition, various development scenarios will be considered based on the extent of the resource and other factors. Because no specific plant design has been proposed for the HGP, a reasonable composite or typical design based on current information will be used to assess potential impacts.

According to the State of Hawaii (DBED 1983); the $500 \mathrm{MW}$ of electrical power was expected to be delivered to the Island of Oahu: A recent evaluationeof

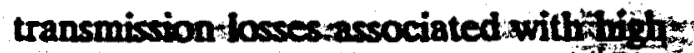
voltagodirect current (HVDC) ted of

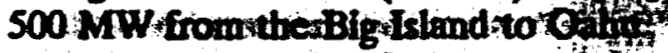
indicates a gross eloctrical generafin

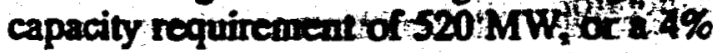
total HVDC transmission system losi including converter station losses (Bonnet 1992). HECO indicated that it was. interested in purchasing up to $500 \mathrm{MW}$ of geothermally generated power. The-Maui Electric Company (MECO) also has indicated zome interest in whether a tap for $50 \mathrm{MW}$ from the project's transmission system is technically, feasible (HECO 1989). Othereconfigutrations of the HGP including moreor tes powerproduction are possible, 
discussed in Sections 3.3.1, 3.3.3, and 3.3.4. In general, support from FWS will include a literature review, native forest bird survey, vegetation community survey, survey of threatened and endangered species, wetland and floodplain inventory, assessment of nonnative species introduction at existing geothermal facilities, and an invertebrate survey. Support from USGS will include a literature review, geothermal fluid characterization, determination of voleanic gas beclyeoud ain quelity, groundwater en iss ions 2.1 resource evaluation, volcanic and deformation hazard anatyses, seismic hazard analysis, estimation of the potential for undersea slides and turbidity currents, and estimation of the potential for induced seismicity. COE will provide a literature review, a wetland map unit legend, and delineation of wetland types.

It is important to note that the proposed FWS, USGS, and COE technical studies are being supported by DOE to satisfy CEQ requirements (40 CFR 1502.22) regarding "incomplete or unavailable information." CEQ states that "If the incomplete information. . is essential to a reasoned (choice among alternatives and the overall costs of obtaining it are not cxorbitant, the agency shall include the information in the environmental impact statement." In 14 addition, thesestudies are-necessary to providendata and analyses sufficient for DOE tojopnduct effective consultations with

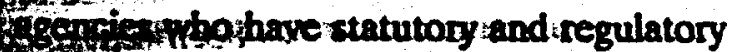

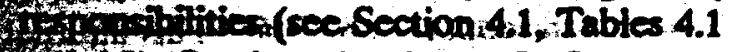

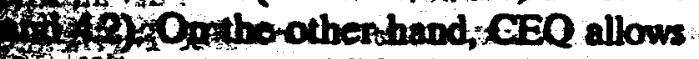
Hat foostomeaprohibitiveand/or the means To obtain information aroun'mown, an tegenoyshall inctude within the invironmental impactistatement: (1) A Laternent that such information is inpomplete:or unavailable; (2) a statement of fifle rance of the incompleter or



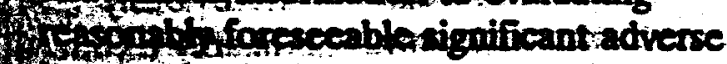

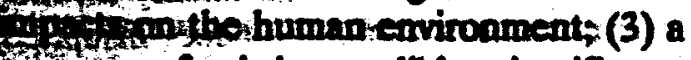

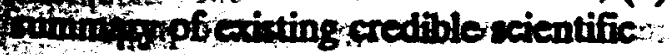

evidence which is relevant to evaluating the reasonably foreseeable significant adverse impacts on the human environment; and (4) the agency's evaluation of such impacts based upon theoretical approaches or research methods generally accepted in the scientific community."

\section{TREATMENT OF ALTERNATIVES}

\section{ALTERNATIVES WITHIN THE PROPOSED ACTION}

\subsection{Development Scenarios}

Forecasts based on resource characterization indicate that from 10 to 20 separate geothermal power plants of from 25 to $50 \mathrm{MW}$ each could be developed under the State's original 1990 HGP proposal. The actual number of plants would depend on the extent of the resource defined in Phase 3. Because the exact location of plants will not be known until Phase 3 is completed, the EIS will rely on best available data and information to encompass the possible impacts at the development sites. Various development scenarios will be preparedufor the EIS.using information that has been collected over the yearm an the

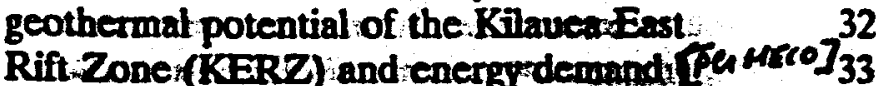
forecasts provided by a HECO :endenthes of ts

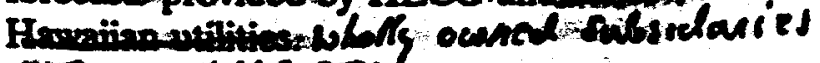

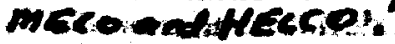

\section{CocthormakTochnologleon:}

Alternative geothermal technologies will be described and considered in the-EIS. Based on the physical characteristics of the geothermal resource and contemporary geothermal energy development practice, the State previously estimated that about:125 production wells and 30 injection:well may be needed ito produce the 500 MWADBED 1992) For the-EIS;-reasonably fortisceable geothermal technology options will be 
H i H

pressurized cables, and low-viscosity, oilimpregnated, self-contained, oil-filled pressurized cables. Solid-dielectric cables present another option. Both aluminum and copper were examined as conductors, but only aluminum was found to be acceptable. Since those studies were performed. technologies have advanced and the bases for costing scenarios have changed. The EIS will review technology advances and review costing for the prior scenarios.

\subsubsection{High Voltage DC vs High Voltage AC Transmission}

Current plans for the submarine cable call for HVDC transmission. During scoping, several commenters suggested that if development is staged, then AC transmission over relatively short distances might be cost effective. This assumption will be examined and the relative environmental impacts of DC vs AC transmission will be discussed based on available literature and experience in other locations.

\subsection{4}

\section{Land-Sea Transtion:} if the

Different land-sea transition ( $^{\mathrm{i}} \mathrm{f}$. (pentcos $f^{1 n}$
$(15)$ configurations will be considered besed on the need for oil pumping stations (to maintain pressure in the cables and $^{\text {and }}$ pistransformers. If a tap to the local system is totirequired, a conversion station may also be moceasary.

\section{1:4.5 Nuliplatlese of the Submaine} Cablow:

Multiple uses of the submarine cable, oncerit is installed and operational, will be considered in the EIS. It has been suggented that the submarine cable could be Chised in a reverse mode to transport felectrical power from Oahu to the other intandar: For ecample; the EIS will consider

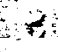

the use of residual fuel oil to produce power on the island of Oahu for use there and for possible export to the other islands via the cable. Commenters have suggested that this alternative may be justified in light of potential liabilities from continued interisland shipping of residual fuel oil.

\section{ALTERNATIVES TO THE PROPOSED ACTION}

Utilities in Hawaii are currently preparing Integrated Resource Plans (IRPs): therefore, supply and demand options cannot be evaluated on the basis of specific projects at specific sites. Rather. alternatives to the HGP need to be evaluated in the context of various energy scenarios for Hawaii's economy for the next 30 years (i.e., the life of the HGP project). For example, a no-action alternative implies an energy scenario in which the conventional resource options now used on the island, that is oil- and coal-fired power generation plants, would continue to play a dominant role. Conversely; an alternative action involving investments in renewable energy resources and energy conservation would shift the resource mix to lesser dependence on comventional supplies. Thus, to tassess the possible environmental and economic impacts of the proposed supply and demand alternatives; it will be necessary to consider alternative energy scenarios for Hawaii.

\section{Noraction}

The no-action alternative is defined as "business as usual," that is, continued reliance on the existing and planned generating mix of resources, which is predominanthy oil-fired capacity with some coal-fired capacity and renewable energy sources. Under the no-action alternative, the energy need for Hawaii, Maui, Molokai, and Oahu would be achieved using supply or demand-side options on each island. 


\section{Altemative Supply-Demand Options}

In addition to no-action, two supply and demand alternatives will be evaluated in the EIS. The first is the development of up to $500 \mathrm{MW}$ of geothermal power for exclusive use on the Big Island, with no inter-island transmission cable. The State of Hawaii's preferted alternative is development of the geothermal resource to meet the projected needs of the Big Island, and submarine cable to export some level of power at a later date if the geothermal resource and project economies justify the cost of a cable. Although a definite geothermal development scenario has not yet been proposed, the EIS will examine an alternative geothermal generating capacity of $100 \mathrm{MW}$ or more (up to $500 \mathrm{MW}$ ) for the Big Island only. The lesser amount represents the geothermal capacity that is currently lige goothermal for permutted development on the Big Istand only. (sof:5a<0)

The second supply-demand option would consist of conservation and demand-side management (DSM) alternatives and a mix of currently feasible renewable energy sources (e.ge, biomass, solar thermal, wind, geothermal, and photovoltaics). DSM refers to the reduction of demand.for energy through electrical load management, energy conservation, and improvements in energy utilization to reduce energy demand.

All alternative supply-demand options will be compared and assessed within the framework of IRP using available data and methods developed for the State utilities? IRP currently in progress. Where possible, the expply demand options will be characterized in terms of their relative cost, fiscal impacts; and contribution to the State's overall energy demand.

\section{ALTERWATVES CONSIDERED BUT EMVIATEDFROMDETALED. Constoration}

Alibough mingaltematives were.

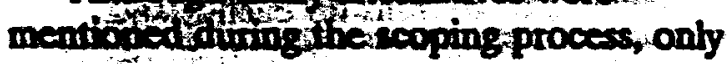

those alternatives deemed to be viable and reasonably foreseeable within the time frame of the proposed action (i.e. 30 years) will be considered. In general. the alternatives that will not be considered in the EIS were either anticipated to be not technically feasible within the project time frame [e.g.. ocean thermal energy conversion, wave and tidal power, and bydrogen as a carrier fuel] or technically feasible but extremely unlikely because of legislative or other impediments.

As an example of the latter, the construction of a nuclear power plant in Hawaii is unlikely because of a State constitutional requirement for a two-thirds vote in each house of the Legislature for such an action (Act XI, Section 8).

During scoping, commentors recommended that the EIS consider transportation alternatives that would reduce petroleum (oil) consumption One of the State's primary reasons for encouraging the development of Hawaii's geothermal resource was to reduce-therState's reliance on imported oil The EIS will address the reduction of oil consumption that would result from the development of geothermal capacity and other alternatives (ie, the aruount of oil replaced by theaproposed geotherimal power generatio wast tother alternatives as part of the ecuergy supplydemand trenarios); but becannosprious. transporthition alternativesurculd notsdirectly affectpower generating acapaitgin inawaii, they will not becvaluated in the EIS

In eddition to alternativerapplydemand optionsthativill not bescon deredin the EIS, there ako are somoraltermatives to geothermal development and transmission systems that are beyond the scope of the EIS. For example, the GRS on-Mavi will not be considered as feasible-because current geothermal information indicates that it has direct heat application only and is not believed to be economia for electricity production and is therefore not comparable to the GRSs on the Big Island..The EIS will also not address undergnound 
October 1991

November 1991

March 1992

July 1902

Seprember 1991

Octoher 1991

Nowemiber 1901

March 1902

Juty 1902

\section{Information Enotidage Meetito}

Puna (icothermal Ventures (included a sile vail); Sierra Cub Legal Defente Fund

Blue Ocean Preservation Sociaty; Campbell Estale; Coral Reef Foundation; Kaupo Ranich; Maui Tomorrow; Pele Defense Fund; Mayor's Energy Advisory Commisslon; Bis Island Papaya Orowert; Big thand Rainforest Action Group with Malu Nina; Citizens for Responible Energy Development with Along Aing Oreenpeace Hewali; Hawall

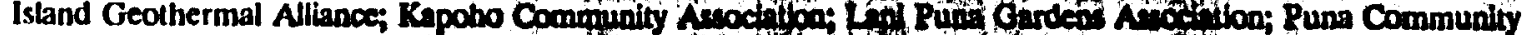
Council; West Hawail Sierra Club; Nattve Hiawalian Lega Corporation; National Auduboo Sodety; Natural Resources Defense Council; Oahu Rainforeat Action Network; Rainforest Action Network; Sierra Club Legal Defense Fund; Jawaii utilitics; Bishop Museum

Native llawaiian Organizations; Pele Defense Fund; Puna Geothermal Ventures (included a site visit); True MidPacific (included a site visit)

Pro. (ieothermal Nliance; Hawail Istand Geothermal Alliance

\section{Cocperating Agency Meetings}

U.S. Department of the Interior (DOI); U.S. Geological Survey (USGS); U.S. Fish and Wildife Service (FWS); National Park Service (NPS); U.S. Army Corps of Engineers (COE); National Marine Fitheries Service (NMFS); U.S. Environmental Prolection Agency (EPA)

Ilawail Department of Business, Economic Development, and Tourism; County of Havail; USOS; NPS; Hawall Oflice of State Planning; Hawail Department of Land and Natural Resources; Hawail Department of Health; Hewwail Office of Environmental Quality Control; NMFS; FWS; COE; Hawail Ofrice of Hawalina Afrairs; Hawail Ofrice of State Planning

County of Maui; County of Hawaii; NMFS; Office of Hawalian Homelands; State Historic Preservation Ofricer; State Office of Consumer Advocacy

County of Ilawaii; USGS; DOI; EPA; County of Maui; Hawaii Department of Business, Economic Development, and Tourism; COF:; NMFS; FWS

Ilawaii Department of Business, Economic Development, and Tourism; Hawail Ofrice of State Planning; Hawail Department of Ilealth; Hawail Office of Hawailan Alfairs; Hawall Department of Labor and Indusurial Retations; Ilawaii Department of Land and Natural Resources; Hawaii Department of Agricullure; EPA; USGS; Hawail Departmemt of Land and Natural Resources; COE; County of Hawali; NPS; USOS; Counry of Maul; Hemoi:Deparmment on Husines, Economic Development, and Toundsm.NMFS; FWS; review of Working Draf Implementation Plan with gooperators

$$
\text { all }
$$


- Thermal and chemical contamination caused by reinjection;

- Impacts to the quality of nearby potable water catchment systems and deep wells;

- Dewatering of and/or reduced yield from groundwater resources which could impact availability and use;

- Transport of contaminants from HGP-related wastes and effects of drilling effluent brine impoundments. both into underground sources of drinking water;

- Erosion control during construction and operation of HGP-related facilities:

- Management of point and nonpoint contamination sources;

- Groundwater monitoring system requirements, including parameters to be monitored (both water quality and elevation of the water table surface);

- Mitigation plan to halt emanating groundwater contamination and/or water table declination detected by groundwater monitoring system;

- Complete geothermal fluid characterization;

- Identification and mapping of nearby potable water wells that could be affected by HGP-related construction and operation;

- Spill prevention, containment, and mitigation methodology;

- Source of water for well drilling.during construction and well quenching during plantoperation; and.

- Well casinguand bydrologicamonitoring planfor both production and reinjection welk.

There is an interrelationship between water resources and geologic resources. Issues related to geologic resources are discussed in Section 3.3.3. Springs and thermal springs are included in the definition of water resources as used in this section; wetlands and anchialine ponds are discussed in Section 33.4.
Water resources are also vital to subsistence and religious practices of Native Hawaiians; cultural uses of water resources are addressed in Section 3.3.9. Marine water quality issues are discussed in Section 3.3.4.

Studies will be undertaken to obtain environmental baseline information that is not available in the open literature.

Cooperating agency involvement will include the State of Hawaii, USGS, and the County of Hawaii. A water resource inventory that will be provided by the USGS, with input from the State of Hawaii and County of Hawaii will be included in the EIS (see Section 4).

The State of Hawaii is considering the status of its water quality designation in the geothermal subzone beneath the District of Puna. All analyses of environmental impacts will be based on the water quality designation in effect at the time of writing of the EIS.

The uses and water quality-of surface and groundwater resources in potential development areas and the effects of the HGP on these-resources wilt bediscussed in the EIS. Hydrogeological data for the HGP site, and vicinity and HGP-sourceterms for potential effluents and contaminants, will be used to assess the potentialforcontaminant deposition and transport-Results of these anabseswill factorinto heathrand: coological assessments. (discussed in Sections 13.7 and 33.4, recpetively) State

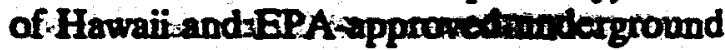
injection regulations anill betentaste basis

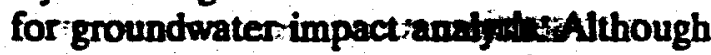
they are not presenthy applicalbleso: catchment systems; Safe Drinking Water Act (Public Law 93-523, December 1974) standards will be the criteria used to gauge the significance of: impacts of atmospheric pollutant deposition in catchment systems. Eesmits issued by the State of Hawaii, as well as written agreements between the State of Hawaii, EPA, and currentgeothermal developers; will besued to assess 
subsidence from routine withdrawal and [perus"s] assessment will require consultation with the reinjection of geothermal fluids during Hawaii Department of Land and Natural power plant operations. Finally, the USGS will assist DOE with groundwater resources, uss 3 / Resources, the Division of Water Resources characterization and geothermal fluid $t P^{4 r}$ Management, and DOH. County chemical characterization. and ses

The HGP EIS will examine the potential for damage to geothermal facilities by fresh lava flows as well as effects of earthquakeinduced phenomena such as excessive ground motion, surface rupture. liquefaction. and landslides. Environmental impacts of accidental release of geothermal fluids will be assessed (see Section 3.3.2). The effects of prolonged withdrawal and reinjection of geothermal fluids during plant operations also will be analyzed (see Section 3.3.2). If possible, reservoir engineering characteristics will be used to predict the nature of induced seismicity, subsidence, and geothermal reservoir depletion (the latter is addressed in Section 3.3.2). These analyses will depend on the availability and appropriateness of existing models. Analysis of routine operational impacts will be based on the assumption that automatic shut-off valves and blowout preventers function as intended and that other reasonable safety features (such as flexible joints between steam gathering lines on the surface and well heads) are included. Accident-driven impacts are discussed in Section 3.3.12.

Soils in the Puna District and on transmission:line rights-of-way will be described from existing ,US.SOil Congtiontervice (SCS) or equivalent surve oonstpuction, operational and accident related impacts (erosion and contamination) to these wills will be assessed (see Section 3.3 .6 and 3.3.4.3). Contamination from accidents and routine spraying (herbicides) of accessiroads; pipetines; plants, and transmission lines will be addreseds:The SCS will beconsulted (see Tablei.1).

Well completion designs and erosion and sedimentrioneontrol plans; (ESGP) will be assessed foc compliance with exitingState governments will be consulted with respect to ESCPs. Effective monitoring of construction- and operation-related erosipn and sedimentation is a regulatory hee uses requirement of an ESCP. In addition NDS and will be consulted during EIS preparation connts regarding volcanic eruption mitigation measures (see Tables 4.1 and 4.2).

\subsubsection{Ecological Resources}

A recurring concern expressed by commenters was the effect of $H \mathrm{HP}$ transmission corridortrandicabletid

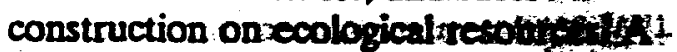
number of commenteonditedith th thess:

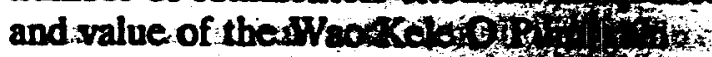

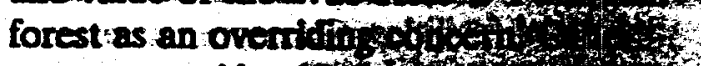

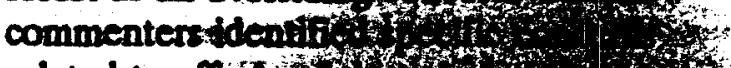

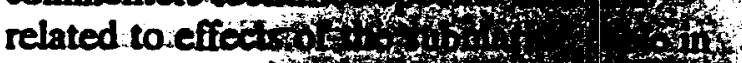
thescosatalson:

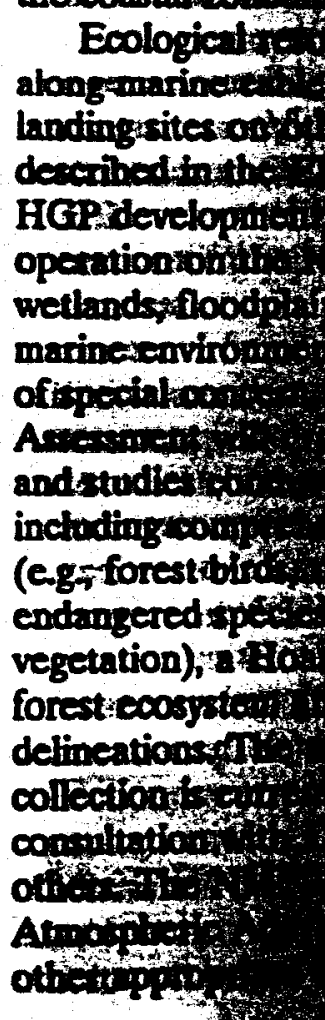
asecect for 
- Potential to cause ciguatera (fish poisoning) as a result of cable construction, deployment. and maintenance in coastal reef areas.

\subsubsection{Terrestrial Resources}

Commenters asked that comprehensive surveys of rain forest species be completed and the results evaluated. Moreover, they thought that the EIS should fully investigate the potential short- and long-term impacts of the HGP to pristine environments, such as the rain forest in Hawaii, the southeast coast and Hana districts of Maui, much of Molokai, the marine environment (see Section 3.3.4.3), and other locations potentially affected by HGP.

The impacts on terrestrial ecosystems will be addressed in the EIS with particular emphasis on the rain forest, wetlands, cave ecosystems (e.g., lava tubes), vegetation, birds, threatened and endangered species, invertebrates, and ethnobotanical and medicinal species. These resources are extremely important to Native Hawaians, fo. whose culture and religion are closely tied to $\mathrm{COC}$ natural resources, (see-Section 3.3.9). Potential impacts of invasion of non-native species as a result of HGP and power transmission corridors will be evaluated; and the impacts to terrestrial ecosystems as the result of controlling non-native plant species with berbicides within the project area will be considered: Associated ristrs of chemical vegotation control (ie, the use of herbicides) on humans is considered in Section:3.3.7.

A Geographic Information System (GIS) data base for the project will be built from existing data bases:and results from studies to be conducted by the FWS (e.g. vegetation community, native bird, threatened and endangeredspecies, and invertebrate surveys) and the.COE (e.g, wetlands) The GIS will benused to integrate the-coological resourceadatarandranatyee potentinlimpactsonterreotrialecosystems and ecosystem components. Analyses include (1) fragmentation of the rain forest from natural occurrences (e.g., lava flows) and artificial occurrences (e.g., road building associated with HGP development);

(2) non-native species invasion into disturbed and natural areas; (3) potential for the project to contribute to loss of native fauna and flora. including impacts from erosion as a result of construction and maintenance operations; (4) land area impact of (a) well pad size and number resulting from initial development and from expansion as the geothermal resource is depleted and (b) road length; (5) alternative iocations of well pads and roads to minimize ecological disturbances; (6) interrelationships among biota, lava flows, and vegetation regeneration; and (7) effects of transmission line EMF on terrestrial fauns; and (8) other issues identified as appropriaterduring data collection.

The extent and type of wetlands within all land areas potentially involvodin the geothermal resource area andialong : transmission corridors will bedetineated aud simificamenecaribed by COE=ITEEPA will aks' be consulted concernifif is ilan ds (see Section 411). The COE will (stathe 1987 COE Wetiand Delineation thento delineate wetlands: Wetlandsting sand.

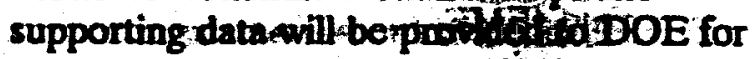

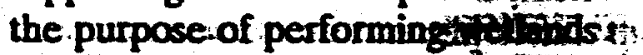

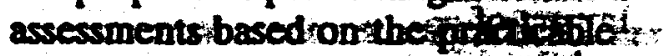

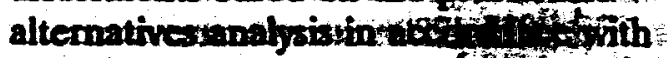

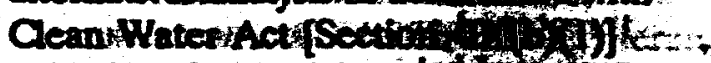

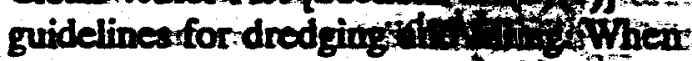

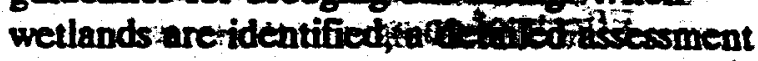
of the potential impacts on thitrietland ecosystem will be made andapproaches for minimizing or avoiding wetlandtinvolvement will be discussed. The assessifist twillinclude potential impacts: on wetland functions, including waterdg thity? hydrology, vegetation composition and structure, habitat for threatened and endangered speciesurand biological diversity.

$$
325
$$


these sources is essential in evaluating and describing various claims that sites within the project area are important for the perpetuation of particular traditional practices and will be necessary for predicting the probable distribution of historic sites in the various areas of potential impact. Where appropriate, the EIS will also address impacts to cultural resources not specifically identified as Native Hawaiian. The Hawaii State Historic Preservation Officer, the Office of Hawaiian Affairs, the Office of Hawaiian Home Lands, NPS, and the President's Advisory Council on Historic Preservation will be consulted as important sources of information and guidance in undertaking the required studies. These archacological and cultural resource surveys will provide the basis for compliance with fortinent federal legislation, including the Aftional-Historic Preservation Act of 1966 (as.amended), Sections 106 and 110; the s ingigan-Indian Religious Freedom Act of H y 4 (mendments proposed); and the 10 offy-American Graves Protection and Xfopatiation Act of 1990. If the project 1 3 irequire placement of dredged or fill 4 Fyt DOE must also initiate Section If indination with the Archacological 10 Preservation Act of 1974. it. prtitution, Article 12, Section 7; Hated Statutes, Chapter 6E; and Hipconcerning religiousand * inhistoric preservation; and Afrind citesprespectively (see $18+(9)$

Hof Natic Hawaianissues inl arcoper of the EIS; these

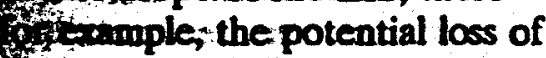
of otheriasueswill be addressed fow went that the relate clearty to 7. - sated by HGP. For example, a A sitigntion invohing Native ty thesdenfromuthosedirectly (t) A, OEvintentroconsult and - *3. Thtive Iawainan through 4 mutually recognized expert consultants and Native Hawaiian organizations that represent various Native Hawaiian viewpoints and concerns. including but not limited to Hui Malama I Na Kupuna O'Hawaii Nei. DOE also intends to consult with the Office of Hawaiian Affairs, an agency in Hawaii charged with representing Native Hawaiian interests and managing ceded lands. By establishing these contacts, DOE seeks to ensure that the EIS [pa MELO $]_{11}^{10}$ accurately reflects to the extent practicab 12 the concerns and issues that Native Sare 13 Hawaiians regard as significant. In addition. 14 DOE will promote wherever possible 15 community access to the results of cultural 16 studies. To the extent possible, consultations 17 on these surveys will extend directly to 18 affected Native Hawaiian communities. 19

\subsubsection{Aesthetic Resources 21}

Commenters stated that the EIS should 23 address the aesthetic impacts of HGP-on all 24 islands, including impacts to natural and 25 agricultural landscapes; beaches, and 26 recreation areas. Specific issues that were 27 identified in the scoping process include: 28

- Visual impacte of clearing land in the $\quad 30$ Wao Kele O Puna rain forest; 31

- Visual impacts of transmissiontines, 32 cable facilitiessand increased erosion; $\quad 33$ particularly in established scenicureas, $\quad 34$ near park and reserve lands and wear $\quad 35$ recreationsareas;?

- Visual impacts of an industrial ticility in 37 a residential and/or rural enviromment; 38

- Aesthetic impacts to the PunarDistrict 39 and along transmission line corridors $\quad 40$ because of HGP-related noise, odor, and 41 night lighting, including potential 42 nuisance impacts of noise (see 43 Section 3.3.5);

- Proximity of HGP facilities to the HVNP 45 in consideration of visual impacts (eg., 46 nighalighting) Air-Quality-Related 47 Values under the Clean Air Act; and 48 
- Off-grid electric power systems (e.g., solar hot water, synthetic natural gas/propane for cooking, wind, etc.) should be considered where possible in assessment of alternatives.

From 1985 through 1989, the State had envisioned a large-scale, 500-MW geothermal/inter-island submarine cable project (the HGP) as an alternative to the State's $90 \%$ dependence on imported oil for electricity generation. However, as of January 1990, the State has redefined its geothermal goal to a planning level that seeks to have geothermal development first meet the requirements of the people of the Island of Hawaii. This downsized project does not include an inter-island submarine cable-system. If this goal is successful, only then swould the State consider a large-scale Us seothermal and inter-island cable project. Whithernatives to the proposed DOE 4t tion (partially funding Phase 3) and 4 Tasponably foreseeable actions by others 4 (such as Phase 4, the proposed construction 7 ind operation of HGP) will be addressed in Whe EIS. These alternatives will include the Wit iscetion altemative of not partially funding 3. 3 . In addition, reasonable altematives 4 Hintheproposed HGP, both supply and 34 tupply, as well as design and location I I ivives will be considered. The criteria 4. 5 tipating alternatives will include and the thengy objectives and policies 2618, HRS, of the Hawaitstate

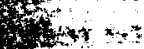
TSP will be evaluated $t o$ determine oryativeshave the potential to 5. milar objectives:The main 4 Nill be in determining the if IGP's contribution to meeting Herution needs and Hawaii's energy Hits $n$ ofreducing reliance on imported 4. F r mination will be based in part 4 ynof electric generation Hindelans to meet these 4t Trmosportation actions that if ills reduce dependence on oil is will not be considered as alternatives to the proposed action. Although these actions have been mentioned during scoping meetings as possible alternatives because they could potentially accomplish one of the proposed action's primary objectives, that is reduce Hawaii's dependence on imported oil. they do not achieve the crucial HGP objective of supplying electric power.

Therefore, this alternative is not considered comparable to the proposed action. The EIS will consider, however, the amount of oil displaced by the use of up to $500 \mathrm{MW}$ of geothermal energy and other supply-demand alternatives.

Alternatives that will be considered include: alternative geothermal technologies, sites, and capacities; alternative supplydemand options, such as no-action, geothermal on the Big Island onty, and conservation and DSM plus renewable. energy supply sources; alternatives: associated with the overiand transmission routes;-and alternative submarine cable-routes and technologies. Alternatives to the proposed ubmarine cable system will includestrarious Eable routes and cable materiak; such as solid dielectric or oil-filled submariv-eables, operation at either HVAC or HVDE, and alternative methods of land-sea tramition. Each of these alternatives will becevaloated based on their cconomic and technical viability. The potential envirommentaltand conomic:impacts for each energyisupplydemand soption will be identific diencintived, and compared to the impacts of the proposed action.

\subsubsection{Alternativesewithin the Proposed Action}

\subsubsection{Devolopment Scenarios}

During scoping, several commenters questioned the need for power-generating capacity where geothermal-derived energy wasteing planned to be delivered-Because the geothermal resource is not yet 
commercially defined, various geothermal development scenarios will be proposed using available information on (1) the geothermal resource potential that may be 1 commercially available and (2) the energy demand forecasts provided by HECO and other-Iowninanutities. These scenarios will Sussidawrsallow for a staged development of

msco and geothermal resources to meet the energy $H Q<C O$. demands projected by the utilities.

\subsection{Geothermal Technologies}

Alternatives to the proposed 500-MW HGP will include various power-generating strategies and power-generating technologies (e.g., total reinjection and in situ heat excbange). Technology alternatives will be selected from the best available information from the State of Hawaii, geothermal developers, utilities; and other experience with geothermal development.

\subsection{Altemative Sites}

In response to scoping comments about. the location of geothermal facilities, alternative sites will also be considered in the EIS. Because the basis for site selection will be the availability of adequate geothermal resources, the EIS will rely on best available information regarding the development potential of the KERZ. Geothermal development on Maui will not be included because the resource is not expected to be economical for power generation.

\subsection{OverlandTransmission Routes}

The scoping process identified the need to consider alternative overland transmission routes and technologies. Potential overland routes, based on configurations described previously in HECO (1989) and discussions with the-Stato:and County of Hawaii, will be defined and will, be discused in the EIS in terms of impacts to land aserecological. resources, health and safety, socioeconomics. cultural resources and Native Hawaiian concerns, and aesthetics. The EIS will not. however, consider underground transmission systems because the costs of such would be prohibitive.

\subsection{Submarine Cable Routes and Technologies}

The concerns identified as environmental (see Section 3.3.4.3), socioeconomic and recreational (see Section 3.3.8), and culturai (see Section 3.3.9) regarding the marine environment will be addressed for each of the alternative cable scenarios.

Cable Routes. The preferred route is at present only roughly defined. Therefore factors relating to competing uses, impacts to water quality and marine coology (particularly to threatened and endangered species), coonomies, impacts to cultural heritage, and risks of credible accidents (see Section 3.3.122) will be important in defining the preferred routes and viable alternatives:

Alternative cable materials and configurations: When the HDWC program analyzed the many possible configurations, an oil-filled cable was considered technically and economically the preferred alternative. Thosecables:that were found to be* technically feasible (HDWG 1985a) will be reexamined froman envirominental

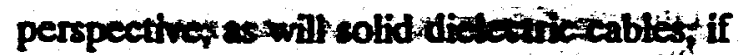
they are demonstrated to berreaconablefrom a technicalandroost basis:

HVDC is HVAC transmiasiotis. The" preferred technological alternative for the submarine cable is HVDC. If HVAC is found to have sufficient technological merit that it can be considered a reasonably foreseeablealternative, then its potential environmental impacts will be considered. Of particular-concern is the EMF-associated with AC, which is considerably greater than that observed for the same power rating with DC current. 


\section{TABLE 4.1. Agency Consultations}

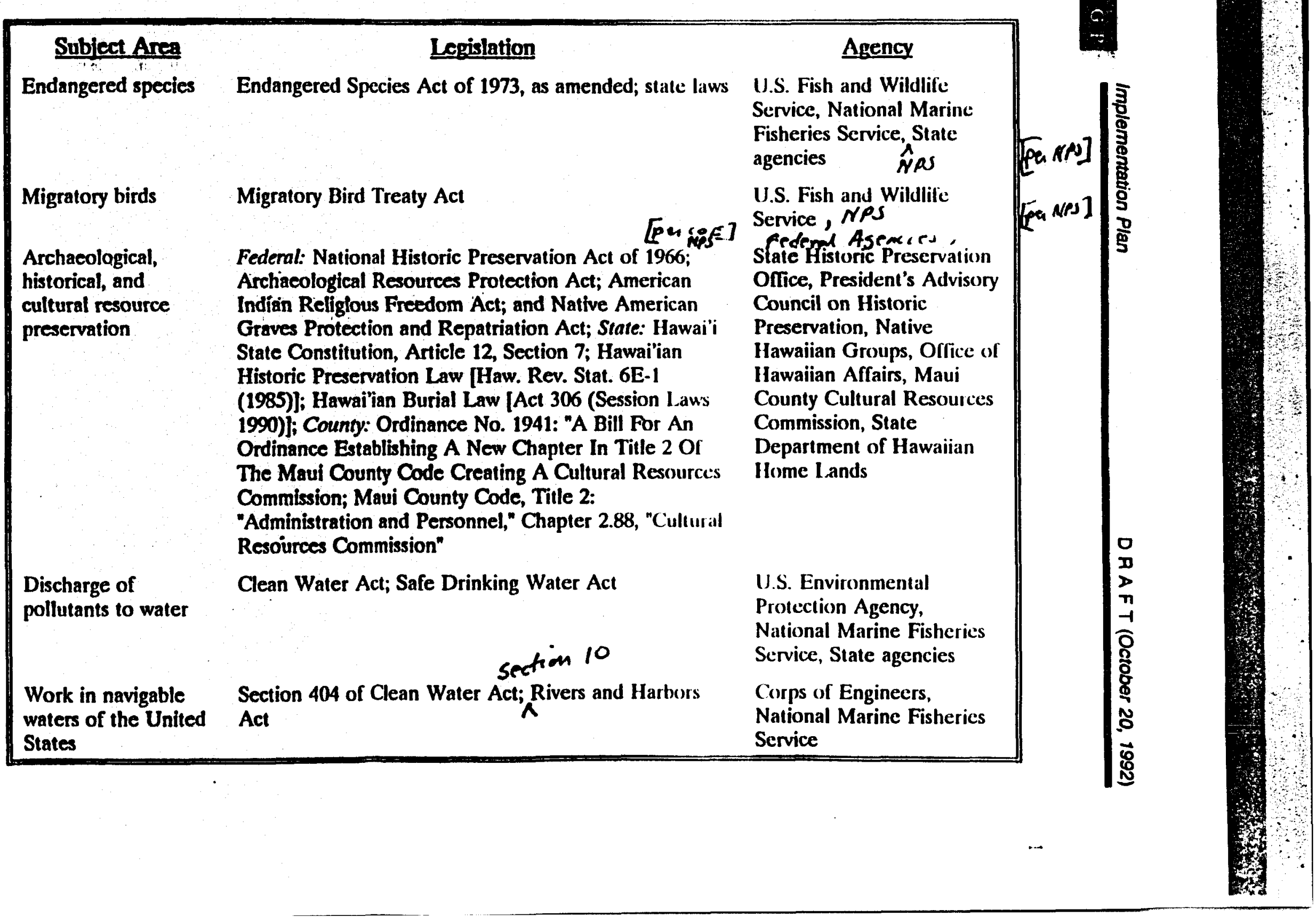


TABLE 4.1.-Agency Consultations (continued)

\begin{tabular}{|c|c|c|}
\hline Subject Area & Legislation & Agency \\
\hline $\begin{array}{l}\text { Prime and unique } \\
\text { farmlands }\end{array}$ & Farmland Protection Policy Act of 1981 & Soil Conservation Service \\
\hline Foodplains & 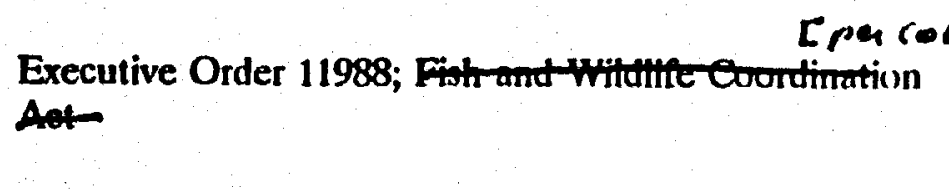 & 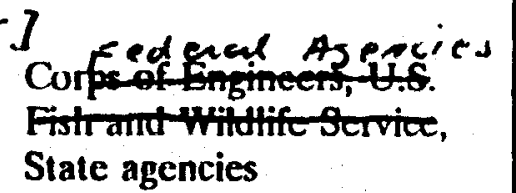 \\
\hline Wetlands & $\begin{array}{l}\text { Executive Order 11990; Fish and Wildlife Coordination } \\
\text { Act; Section } 404 \text { of Clean Water Act } \\
\text { [Pa cos.] }\end{array}$ & $\begin{array}{l}\text { Corps of Engineers, U.S. } \\
\text { Fish and Wildlife Service, } \\
\text { Setiont Mtatime Fisheries } \\
\text { U.S. Environmental } \\
\text { Protection Agency }\end{array}$ \\
\hline $\begin{array}{l}\text { Water body } \\
\text { alteration }\end{array}$ & 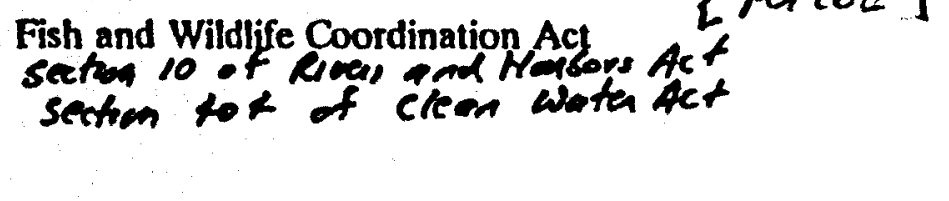 & $\begin{array}{l}\text { U.S. Fish and Wildlife } \\
\text { Service, National Marine } \\
\text { Fisheries Service, State } \\
\text { agencies ; Copps of Eg eree }\end{array}$ \\
\hline River status & $\begin{array}{l}\text { Wild and Scenic Rivers Act; Anadromous Fish } \\
\text { Conservation Act; Hanford Reach Study Act }\end{array}$ & $\begin{array}{l}\text { U.S. Department of the } \\
\text { Interior }\end{array}$ \\
\hline Air pollution & Clean Air Act & $\begin{array}{l}\text { U.S. Environmental NPS } \\
\text { Protection Agency, State } \\
\text { and local agencies }\end{array}$ \\
\hline $\begin{array}{l}\text { Water use and } \\
\text { avathability }\end{array}$ & 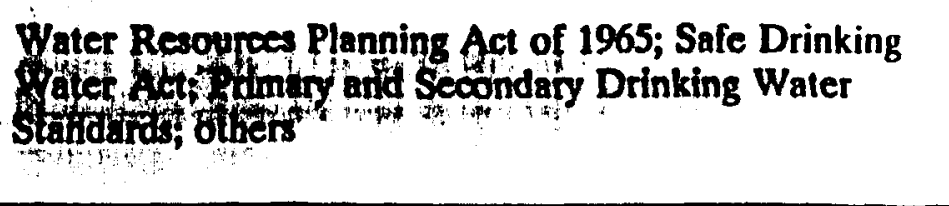 & $\begin{array}{l}\text { U.S. Environmental } \\
\text { Protection Agency, Ofrice } \\
\text { of Water Policy, State } \\
\text { agencies }\end{array}$ \\
\hline
\end{tabular}


TABLE 4.1.-Agency Consultations (continued)

\begin{tabular}{|c|c|c|}
\hline Subject Area & $\begin{array}{l}\text { Legislation } \\
\end{array}$ & Agency \\
\hline Noise & $\begin{array}{l}\text { Noise Pollution and Abatement Act of 1970; Noisc } \\
\text { Control Act of } 1972\end{array}$ & $\begin{array}{l}\text { U.S. Environmenta/yas } \\
\text { Protection Agency, State } \\
\text { agencies }\end{array}$ \\
\hline Siting and planning & State and County legislation & State and ciounty agencies \\
\hline $\begin{array}{l}\text { Waste management } \\
\text { and transportation }\end{array}$ & $\begin{array}{l}\text { Solid Waste Disposal Act, as amended by the Resource } \\
\text { Conservation and Recovery Act and the Hazardous and } \\
\text { Solid Waste Amendments of 1984; Comprehensive } \\
\text { Environmental Response, Compensation and Liability } \\
\text { Act; Emergency Planning and Community Right to } \\
\text { Know Act }\end{array}$ & $\begin{array}{l}\text { U.S. Environmental } \\
\text { Protection Agency, U.S. } \\
\text { Department of } \\
\text { Transportation, State } \\
\text { agencies }\end{array}$ \\
\hline Coastal zones & $\begin{array}{l}\text { Coastal Zone Management Act; State and County } \\
\text { legislation }\end{array}$ & $\begin{array}{l}\text { Otfice of Statc Planning, } \\
\text { County Planning } \\
\text { Department }\end{array}$ \\
\hline
\end{tabular}


TABLB 4.2-Government Agency Permis Consultation List (continued)

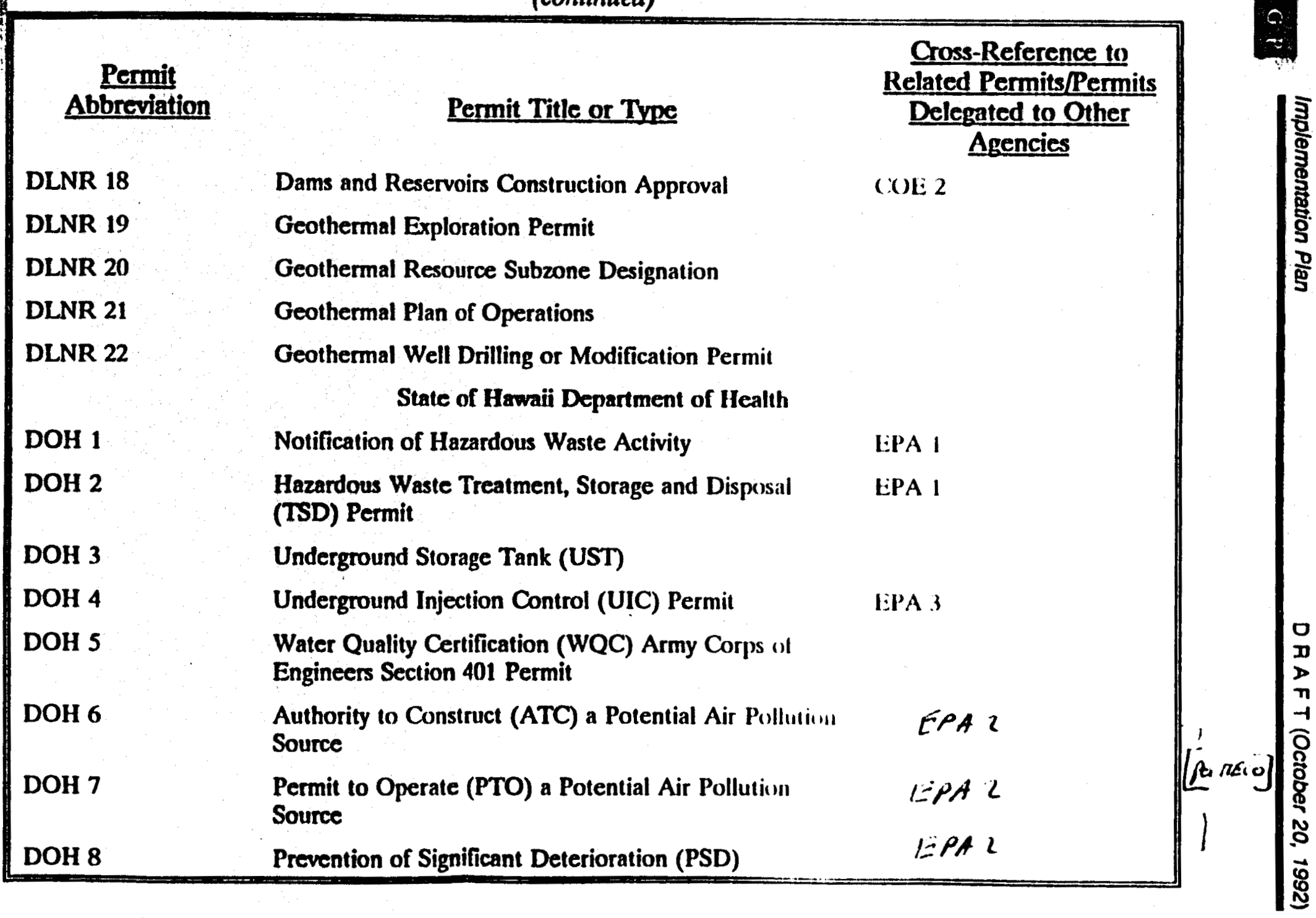


TABLE 4.2-Government Agency Permit Consultation $l$ ist

(continued)

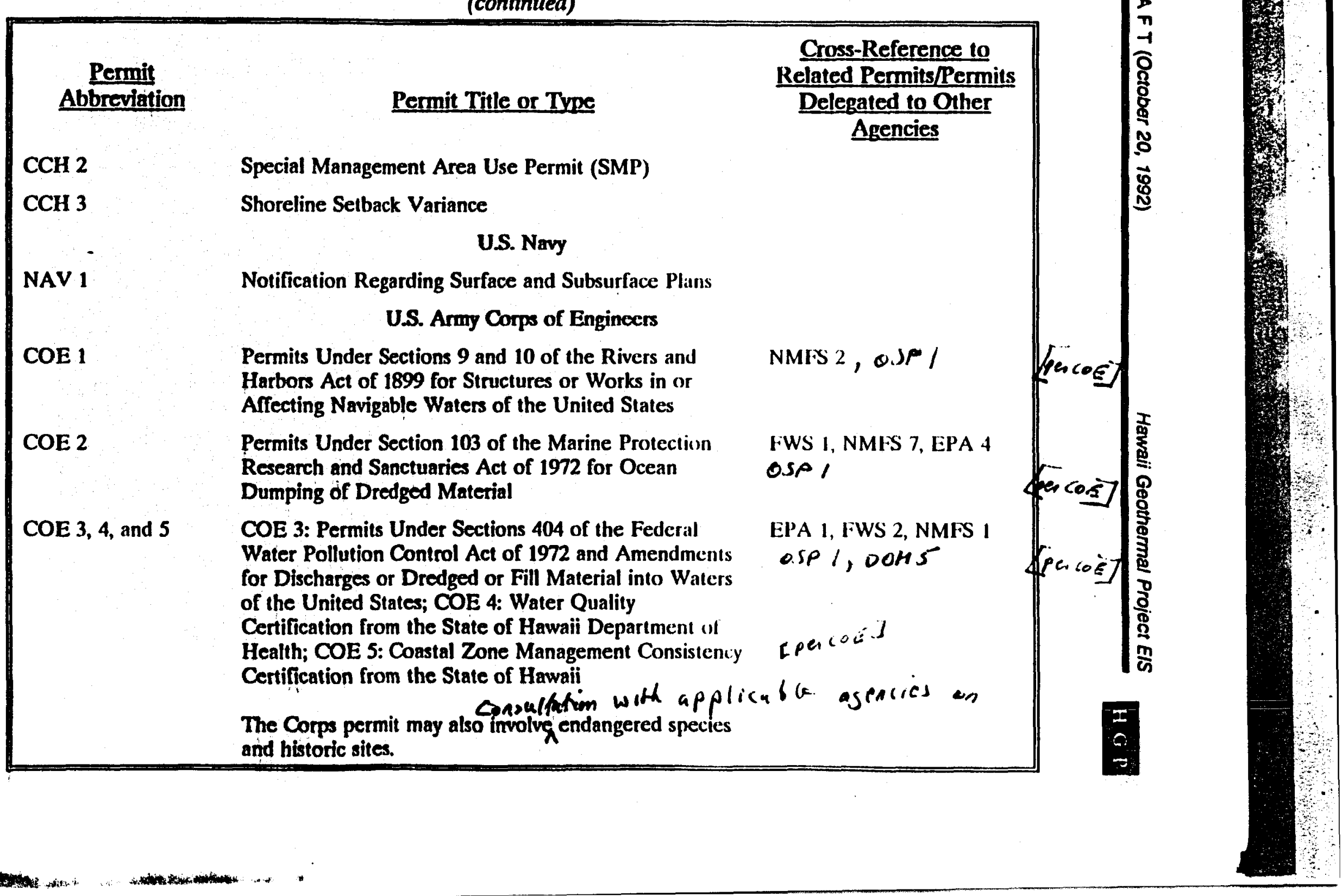


TABLe 4.2-Government Agency Permil Consultation List (continued)

\begin{tabular}{|c|c|c|}
\hline \\
\hline Permit & & $\frac{\text { Cross-Reference to }}{\text { Related Permits/Permits }}$ \\
\hline Abbreviation & Permit Title or Type & $\begin{array}{c}\text { Delegated to Other } \\
\text { Agencies }\end{array}$ \\
\hline NMFS 3 & $\begin{array}{l}\text { Clean Water Act Section 401, Water Quality } \\
\text { Certification Application Review }\end{array}$ & COE 4, FWS 2, EPA I \\
\hline NMFS 4 & $\begin{array}{l}\text { Federal Coastal Zone Management Consistency } \\
\text { Determination Review }\end{array}$ & OSP 1 , COE 5 \\
\hline NMFS 5 & Marine Mammal Protection Act (MMPA) Exemption & \\
\hline NMFS 6 & $\begin{array}{l}\text { The Endangered Species Act (ESA) Section 7, } \\
\text { Consultation Process }\end{array}$ & FWS 1 \\
\hline NMFS 7 & $\begin{array}{l}\text { Marine Protection Research and Sanctuaries Act ol } \\
\text { 1972, Section } 103 \text { Permit Review }\end{array}$ & COE 2 \\
\hline NMFS 8 & $\begin{array}{l}\text { National Environmental Policy Act, EIS preparation } \\
\text { and review }\end{array}$ & \\
\hline NMFS 9 & Fish and Wildlife Coordination Act & FWS 4 \\
\hline & U.S. Environmental Protection Agency & \\
\hline EPA 1 & $\begin{array}{l}\text { Permits and Licenses Under Section } 402 \text { of the Federial } \\
\text { Water Pollution Control Act of } 1972 \text { and Amendments }\end{array}$ & $\begin{array}{l}\text { DOH 1, DOH 2, FWS } 2 \text {, } \\
\text { COE } 3\end{array}$ \\
\hline EPA 2 & Permits and Licenses Under the Clean Air Act & DOH 6, DOH 7, DOH 8 \\
\hline EPA 3 & Underground Injection Control (UIC) Permit & DOH 6 \\
\hline EPA 4 & $\begin{array}{l}\text { Ocean dumping permits under Sect. 102(a) of the } \\
\text { Marine Protection Research and Sanctuaries Act of } \\
1972\end{array}$ & COE 2 \\
\hline
\end{tabular}


H ( ; r

ATTACHMENT 1 - DOE Reading Rooms with Copies of the

HGP EIS Public Scoping Mceting Transcripts

Hawaii

Hawaii Energy Extension Service

Hawaii Business Center

99 Aupuni Street, Room 214

Hilo, HI 96720

Contact: Andrea Beck

Telephone: (808) 933-4558

Fax: (808) $933-4602$

Hilo Public Library

300 Wajanuenue Avenue

Hilo, HI 96721-0647

Contact: Claudine Fujii

Telephone: (808) 935-5407

Fax: (808) 933-4658

Kailua-Kona Public Library

75-138 Hualalai Road

Kailua-Kona, HI 96740

Contact: Irene Horvath

Telephone: (808) 329-2196

Fax: (808) 326-4115

Mountain View Public and School Library

Highway 11

Mountain View, HI 96771

Contact: Evelyn Garbo

Telephone: (808) 968-6300

Fax: (808) 9686056

Pahala Public and School Library

Pakalana Street:

Pahala; HI 96777

Contact: Lisa Cabudol.

Telephone: (808) 928-8032

Fax: (808) 928-6199

Pahoa Public and School Library

15-3038 Puna Road

Pahoa, HII 96778

Contact: Laura Ashton

Telephone: (808) $965-8574$

Fax (808) $965-7170$
State of Hawaii

Department of Business. Economic

Development \& Tourism

Hilo Office

99 Aupuni Street. Room 212

Hilo, HI 96720

Contact: Michelle Wong-Wilson

Telephone: (808) 933-4600

Fax: (808) $933-4602$

Kanai

17

Kauai Office of Economic Development 18

444 Rice Street, Room 230

Lihue, HI $96766 \quad 20$

Contact: Glenn Sato 21

Telephone: (808) 245-7305 22

Fax: (808) 245-6479 23

Lihue Public Library 25

4391-A Rice Street $\quad 26$

Lihue, HI 96766 Lasac 27

Contact: Karen Ikemoto

Telephone: (808) 245-3617 Lanai Aullit ciad 29

Fax: (808) 246-0519

Fraseravene. 30 po doxil-199 31 Lineicity,ftros 32

Mari contht: Pesgs Frit:

rel:

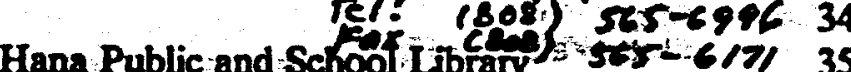

Hana Highway 36

Hana, HI 96713 . 37

Contact: Jeremy Kindred $\quad 38$

Telephone: (808) 248-7714 39

Fax (808) 248-7438 40

Kahului Public Library

90 School Street 43

Kahului, HI 96732

Contact: Lani Scott 45

Telephone: (808) 877-5048 46

Fax: (808) 871-9032 47 


\author{
Pladaras Departratent \\ Maui Energu twatmion Setvice \\ Wailuku. HI 96793 \\ Contact: Kalvin Kobavashi \\ Telephone: (808) 243.7832 \\ Fax: (808) 2437870 7634

\section{Molokai} \\ Molokai Public Library \\ Ja Maloma Street \\ Kaunakakai. HI 96748 \\ Contact: Sri Tencate \\ -elephone: (808) 553-5483 \\ Eax: (808) 553-5958
}

=50 200 South High Street Enegy Divisirm

\section{Oahu}

Hawaii State Library, Document Center

Unit, 634 Pensacola Street

Honolulu, HI 96814

Telephone: (808) 586-3535

Fax: (808) 586-3584

Kahuku Public and School Library

56490 Kam Highway

Kahuku, HI 96731

Contact: Jean Okimoto

Telephone: (808) 293-9275

Fax: (808) 293-5115

Pearl City,Public Library

1138: Waididion Home-Road

Pearl City, HI 96782

Contact: Marilyn Van Gieson

Telephone: (808) 455-4134

Fax: (808) 456-4407

State of Hawaii, Department of Business,

Economic Development \& Tourism

Energy Division, Publications Section

335 Merchant Street, Room 110

Honolulu, HI 96813

Contact: Maurice Kaya

Telephone: (808) 547-3800

Fax (808) 587-3820
State of Hawaii

Department of Business. Economic

Development \& Tourism

Geothermal Office

Financial Plaza of the Pacific

130 Merchant Street. Suite 1060

Honolulu. HI 96813

Contact: Dean Nakano

Telephone: (808) 587-3812

Fax: (808) $587-3820$

State of Hawaii

Department of Business. Economic

Development \& Tourism

Information Office

220 South King Street, Suite 1100

Honolulu, HI 96813

Contact: Marsha Anderson

Telephone: (808) 586-2405 or 586-2406

Fax: (808) 586-2427

State of Hawaii

Department of Business, Economic

Development \& Tourism, Library

220 South King Street, Fourth Floor

Honolulu, HI 96804

Contact: Anthony Oliver

Telephone: (808) 586-2425

Fax: (808) 586-2452

U.S. Department of Energy

Pacific Site Office

Prince Kuhio Building

Room 4322

300 Ala Moana Boulevard

Honolulu, HII 96813

Contact: Eilieen Yoshinaka

Telephone: (808) 541-2563

Fax: (808) 541-2562

Waimanalo Public and School Library

41-1320 Kalanianaole Highway

Waimanalo, HI 96795

Contact: Nina O'Donnell

Telephone: (808) 259-9925

Fax: (808) 259-8209 
This appendix summarizes written scoping comments that were received from federal. State, and County agencies concerning the HGP EIS.

\section{COUNTY AGENCIES}

County of Hawaii

In a March 6, 1992 letter accepting cooperating agency status and in an August 3. .992 review of the woriking draft implementation Plan. the County of Hawaii requested that the following issues be considered in the EIS:

Socioeconomics. Impacts of industrialization of the Island of Hawaii (resulting from geothermal development and power availability) should be investigated in the EIS. An analysis of project costs should included consideration of relocating nearby residents and insurance costs during construction and operation. Utility rates with geothermal development should be compared to rates from alternatives.

Air Quality. The EIS should assess air quality effects of venting during power outages (grid failure) and consider problems associated with fred monitoring systems.

Health and Safery. The EIS should consider effects from hydrogen sulfide and other pollutants at various concentrations and from possible oynergistic effects of pollutants.

Ecological Rescauces. Impacts of emissions on species othen than humans sbould be considered.

Water-Resouncess The "fate" (ie, migration) of reinjected fluids and the impacts thereof should be examined in the EIS.

Sources and amounts of well-quenching water should be identified.

Land Use. The. EIS should assess impacts of incompatible land uses.

Policy. Federal liablilty in federally funded projects should be discussed.

Other. The EIS should investigate the interconnection of the Islandigrid and the interisland grid and discuss priorities under various load shedding scenarios.

County of Maui

In letters of October 1,1991 and April 13, 1992 and in responses to the working draft Implementation Plan. the County of Maui requested that the EIS consider all potential impacts associated with the overland transmission corridor. including possible effects on land use. ecological resources, water resources, scenic resources, cultural and archaeological resources, health and safety particularly as related to the electromagnetic field, and economic issues, particularly effects on property values. If cable landing on Lanai is a reasonable alternative, the EIS should consider these issues as they relate to Lanai.

The EIS should consider the underwater cable's potential economic, cultural, archaeological, and ecological impacts on the reef and fishpond resources along the south shore of Molokai. Lastly, the EIS should reflect recommendations made in the community plans.

28
28
29

STATE AGENCIES 30

State of Hawaii : 32

33

The State of Hawaii offered comments in $\quad 34$ response to the ANOIfytheNOI, the . $\quad 35$ invitation to becomea cooperating agency, . 36 and in reviewing the-working draft Implementation Plan. The communications are from the Office of State Planning, the Department of Business and Economic sp Development, the Office of Hawain S Affairs, and the Division of Consumer Advocacy and are dated September 26 and September 30 of 1991; March 2, March 23, April 2, April 8, and July 24 of 1992.

Energy Policy. The state of Hawaii would like recognized in the ES that its current

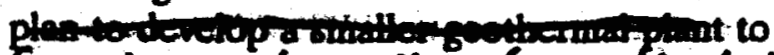

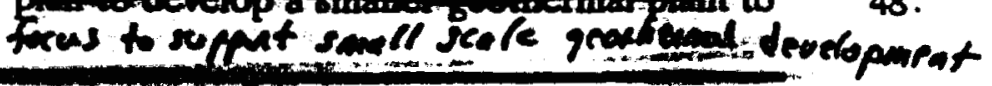


Federal state, and local governments and

gre geothermal developers. The state recommends

t a discussion of the relationship between

) 24 Phases 3 and 4 and existing geothermal

5 projoctse included in the EIS $\rightarrow$ he EIS

- f should alsa.include information about

, सule relations between the federal, state and local y

governments, developers, and citizens.

Land Use. The EIS should at least

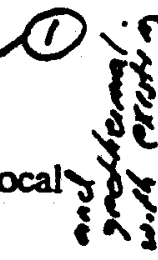

4 tr sil estimate the amount of land area that would 3 of be required for such a large operation. The $x$ discussion should indicate whether the total 2 acreage needed will be concentrated in one $\psi x^{i}$ central area or scattered throughout the Island of Hawaii. Also, a map should be included to show.possible sites for power

stations and the geothermal wellifids. Other concerns are the implications of land use after the plant is closed. The EIS should explain what will happen to the sites after the plants have surpassed their energy generating 5 capacities and when that is likely to happen.

- The EIS should examine the compatability of is e geothermal development with existing and Y planned land uses. (3)

है

Air Quality. The EIS should also discuss the effects of wellfield construction, well

venting, accidents, smell of hydrogen sulfide

and other gases. Although the volcano

produces hydrogen sulfide and causes acid

- rain effects, hydrogen sulfide concentrations

t may be higher in localized areas near the

5 plants. A monitoring and remediation

₹ program should be described. A map should

K. also be included to indicate what areas and

\& communities are likely to be impacted. People

(N) may be able to detect hydrogen sulfide levels below instrument detection. (2)

Water Resources. The EIS should evaluate the effects of hydrogen sulfide and other airborne emissions, not just solid and liquid wastes as proposed in the prep notice, on groundwater and surface water (fresh and marine). Water catchment systems should also be considered a potentially affected resource and the effects of well venting and accidents on them should be determined. The nonpoint source pollution impacts on water quality should also be described. And the proposed monitoring and remediation program should be included and described.

Ecological Resources. The effects from the cable on all marine fauna (not just benthic) including Hawaiian monk seak need to be evaluated. There may be water column impacts, fisheries impacts, impacts on surf sites, swimming and boating. Reefs, beaches and other natural resources such as limu, may be affected. A monitoring program should be developed to evaluate effects on ecological resources on an ongoing basis throughout the duration of the project. Baseline studies and stress indicators should be identified for monitoring. The EIS should also include a description of the impacts on endemic flora and fauna. Acid rain effects on ecological resources should be considered.

Geological Resources. The EIS should f evaluate shoreline and nearshore impacts from the cable, including shore erosion, interference with currents and sand transport, reefs and surf sites. Impacts from the longterm presence of the cable should be included and not be limited to placement and construction activities.

Noise. The EIS should evaluate long-term effects on flora and fauna and their habitat. as well as on nearby residential communities.

Health and Safety. The EIS should also include long-term bealth effects due to chronic exposure to noise, air pollution. water pollution, electromagnetic field and psychological stress incurred from evacuations and the threat of evacuations. The physical and psychological welfare of residents in nearby communities must be evaluated. Public health monitoring should be provided.

Socioeconomic. The effects of lifestyle changes and disruption need consideration. Frequent evacuations and the threat of 
$\rightarrow \dot{5}$

$5:$

72

है

socioeconomic future may be sacrificed for the vague promise of energy self-sufficiency.

\section{lopatify as ents OHA Vrea FEDERAL AGENCIES \\ Coa son DQEO)}

National Marine Fisheries Service

In a March 6, 1992 letter and in comments on the working draft
Implementation Plan, the National Marine 1

Fisheries Service (NMIS) characterized issues 2

related to the underwater cable as important 3

and sensitive. Two specific issues were 4

identified for consideration in the EIS: 5

impacts of the electromagnetic field on 6

marine biota and impacts from trenching and 7

laying transmission lines on nearshore marine $\quad 8$

habitats; including coral reefs. 9

National Parteservice 11

In letters of February 24, 1992 [Hawaii 13

Volcanoes National Park (HVNP)], 14

February 28, 1992 [Pacific Area Office 15

(PAO)], April 14, 1992, and in 16

Implementation Plan reviews of July 14, $1992 \quad 17$

(HVNP) and July 17, 1992 (PAO), the 18

National Park Service offered the following 19

comments. 20

The EIS should address potential impacts 21

to HVNP, a Prevention of Significant 22

Deterioration (PSD) Class I area. The Park is 23

concerned about the potential for air 24

contamination which might affect native 25

\% plants and animals or might adversety affect 26

$\checkmark$ the health of visitors and employees: An : 27

F Junbiased analysis of point source emissions 28

F Eand an evaluation of impacts resulting from 29

exissions of hydrogen sulfide and criteria and 30

t. ntunon-criteria air pollutants and particulate

3 . Themissions should be condueted. Cumulative 32

and long-term effects of emissions and 33

electromagnetic fields should be considered. $\quad 34$

The EIS should analyze potential loss of $\quad 35$

Air Quality Related Values (AQRV), 36

including vista degradation, noise, and odors, $\quad 37$

which are important to the Park's mandate to $\quad 38$

manage the backcountry for wilderness $\quad 39$

values. Light contamination should be . $\quad 40$

considered, as should cumulative impacts of 41

noise (including that generated by scenic tour $\quad 42$

aircraft). Mitigation measures should be 43

discussed. 44

The NPS expresses concern over the 45

introduction of industrial land use in a region $\quad 46$

characterized by conservation, agricultural and 47

rural land uses. The EIS should include $\quad 48$ 
regional land use issues. including maintaining buffers around state and national protected areas.

Impacts to the threatened Newell's Shearwater, recently spotted near HVNP. from lights, noise, drill rigs, overhead wires. fences, and emissions should be considered.

The NPS reports that emergency remedies to thwart lava flow are not allowed in HVNP.

The NPS requests that energy conservation be considered as an alternative.

\section{U.S. Army Corps of Engineers}

in its August 26, 1992 review of the working draft Implementation Plan, the Corps noted that it has no plans to do any work on describing the rainforest and will not develop a GIS base for wetlands. In addition, the Corps raised the following points:

COE will not consult with DOE SCS, USGS, or FWS in the wetland delineation is efforts and will not consult with those if is agencies regarding wetland significance or i's 'Af values,DOE will make a detailed carth assessment to satisfy 404 (b)(1) guidelines ic $\mathrm{h}^{\mathrm{A}}$ to tor the discharge of dredged or fill of material DOE should ako be aware that the 404(b)(1) sequence involves avoiding fill, minimizing fill, and mitigating for fill.

- DOE must initiate Section 106 Historic Coordination for any discharge of dredged or fill material, as:well as for the geothermaldevelopment.

- In Table 42 pf the Implementation Plan, EPA shouldberadded to.COE 2; and USFWS, NMFS, and ACHP should be added to COE 6. The Corps permit may also involve endangered species and historic sites.

- The EIS milestone schedule is very tight. Our experience indicates that 18 months from start of writing to decision point is very fast. COE may not be-able to perform with any accuracy with this schedule.

\section{U.S. Environmental Protection Agency}

EPA responded on April 15, 1992 to the NOI with a three-page letter with nine pages of comments covering nearly the full range of technical issues expected to be addressed in the EIS. Generally, EPA's recommendations about the topics to be covered in the EIS are consistent with DOE's. EPA also raises several issues - primarily regarding procedures and alternatives - which relate to DOE policy. Additional comments were made in their August 18, 1992 review of the working draft Implementation Plan.

Policy

1. EPA requests that DOE publish a notice of a draft IP and solicit comments on the decisions DOE considers to be within the scope of the EIS. This procedure will provide a chance for public comment prior to the DEIS. EPA believes that DOE-intends to use the IP-process to make substantive decisions: regarding preparation of the DEIS Further, EPA states that making the final IP available in public reading rooms would eliminate any further public input into DOE decisions until the DEIS is published, scheduled for carty 1993.

2. DOEshould be ready to prepare a supplemental environmental document if the decision about specific plant locations is madoafter the EIS is completed the decision makes substantial chdng - in- the proposed action or if the decisioniti.. relevant to the environmental concerns of the action or its impacts. The EIS should acknowledge the need for environmental documents.for specific plants and inchude plans.to-prepare them in the EIS.

3. An EIS completion date of "early 1993" should not be cast in concrete; doing so may preclude important studies. Time should be allowed for essential studies to go forward. 
$\mathrm{HCI}$

This appendix presents an outline of the Environmental Impact Statement for the Hawaii Geothermal Project. The outline is subject to change as preparation of the EIS progresses.

\section{TABLE OF CONTENTS}

LIST OF FIGURES

LIST OF TABLES

LIST OF ACRONYMS AND ABBREVIATIONS

$\therefore$ PURPOSE OF AND NEED FOR THE PROPOSED ACTION AND PROJECT

1.1 INTRODUCTION

.2 PURPOSE AND NEED

1.3 BACKGROUND OF THE PROJECT

i.4 SCOPE OF THE EIS

$\therefore$ THE PROPOSED PROJECT AND ALTERNATIVES

2.1 THE PROPOSED PROJECT

2.2 ALTERNATTVES TO THE PROPOSED PROJECT

2.2.1 NO ACTION

222 ALTERNATTVE SUPPLY-DEMAND OPTIONS

2.2.2.1 Non-Geothermal Options

2.2.2. Geothermal on the Big Island Only

222.3 Mix of Conservation and Renewables

2

2.3 ALTERNATIVES WTHHN THE PROPOSED PROJECT

2.3.1 Geothermal Technologies, Sites, and Capacities

2.3.2 Overland Transmission Routes and Technologies

23.3 Submarine Cable Routes and Technologies

24 COMPARISON OF ALTERNATIVES

3. AFFECTED ENVTRONMENT

3.1 LAND FEATURES, GEOLOGY, AND SOIIS

3.1.1 Land Features

3.1.2 Geology and Soils

3.2 WATER RESOURCES

3.2 .1 Surface Water.

3.2 .2 Groundwater

3:31 METEOROLOGY AND AIR QUALITY

3.4 ECOLOGICAL RESOURCES

3.4.1 Terrestrial Ecology

3.4.2 Aquatic Ecology

3.4.3 Marine Ecology

3.4.4 Wetland Resources

3.4.5 Threatened and Endangered Species

3.5 EMERGENCY PREPAREDNESS

3.6.2 Land Use

3.63 Housing

3.6.5 Utility Rates and Taxes 


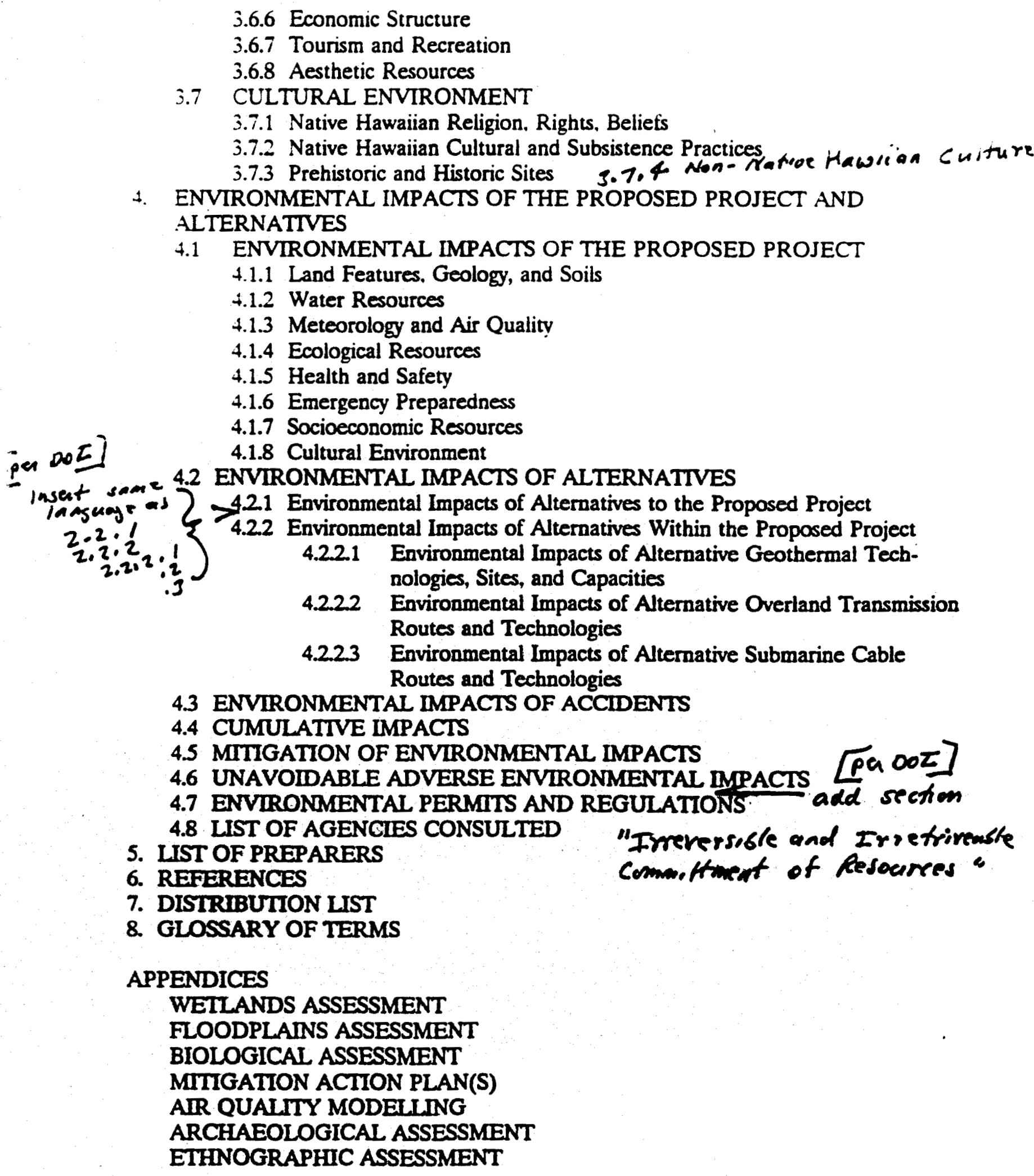


indigenous-having originated in or naturally occurring in a particular region or environment.

injection well-a well into which water, spent brines, or gases are pumped in order to maintain subterranean pressure or to dispose of waste fluids.

integrated resource planning (IRP)-attempts to tind the lowest cost for meeting energy lemand through increasing supply or improving end use energy efficiency.

inverzeorate-species that lacks a spinal column, includes insects, worms, and the like.

megawatts $-1,000,000$ watts ( 1 million watts).

meteorological - of or relating to the science that deals with the atmosphere and its phenomena.

milestone-a significant point in development with the passage of time.

mitigation-refers to measures implemented to reduce an environmental impact to acceptable levels.

non-native species-a species that does not occur naturally where it is found.

particulate-finesolid particle that remains individually dispered in gases and stack emissions.

petroleum refining residuals_high boiling fraction remaining after removal of more volatile liquids.

potable-refers to water that is suitable for human ingestion.

production well-a well from which geothermal brines or steam is extracted. rain forest-a tropical woodland with an annual rainfall of at least 100 inches and marked by lofty broad-leaved evergreen trees forming a continuous canopy.

reinjecrion-the return of water, spent geothermal brines, or gases via an 7 injection well after use in a power plant. 8

renewable energy-nondepletable energy (e.g., $\quad 10$ solar, wind.)

rifi-(geology)-1) the boundary between crustal plates that are separating from one $\quad 14$ another; and 2) fissures that radiate :5 outward from a volcano into which 16 magma (lava) is injected. $\quad 17$

scoping process-refers to the methods by $\quad 19$ which public and agency input are 20 solicited regarding environmental issues to 21 be addressed in an environmental impact 22 analysis. 23

seismic-pertaining to enerpy released by ground motion. $\quad 26$

silicates-common minerals in the earth's crust 28 consisting of silicon and oxygen in ratios 29 varying from $1: 2$ to $1: 4$. 30

socioeconomics-relating to or combination of social and cconomic 33 factors. $\quad 34$

solid dielectric cable-one whose insulator is $\quad 36$ one of several solid materials such as $\quad 37$ ceramic, mica, glass, plastic film, or paper. $\quad 38$

stagnation-absence or cessation of movement, $\quad 40$ growth, or activity. $\quad 41$ 
subsistence-the condition of remaining in existence: the minimum (as food or shelter) necessary to support life.

subzone-GRS-Geothermal Resource Subzone (there are 3 subzones: upper, middle and lower) in Kilauea's east rift geothermal resource zone.

synergistic effects-an action where the total effect of two or more components in a nixture is greater than the sum of their individual effects.

:ephra-denotes all rocks composed of fragmented volcanic products ejected during eruption. Used in this EIS to denote the portion of lava released airborne during eruption.

transport pathways-the paths (routes) that contaminants take between contaminant sources and receptors; these contaminant paths may be air-borne, water-borne or groundwater borne.

tsunami-a long-period sea wave produced by an earthquake, submarine volcanic eruption or other submarine disturbance. vog/volcanic smog -a natural aerosol containing a mixture of volcanic dust particles and volcanic gases. mainly water vapor, carbon dioxide, and sulfur dioxide.

volcanic dike-a tabular body of rock. congealed from magma (lava) injected into fissures or rift zones.

weil blowout-uncontrolled venting of liquids and/or gases from a well.

well casing-tubing inserted into a drill hole to serve as atinear. liner

well quenching-introducing cool water into a well that is out of control to reduce the production of steam, thereby bringing the well under control.

well venting-release of well fluid to the atmosphere, either controlled or uncontrolled.

wetlands-areas such as swamps, marshes, bogs and estuaries; to be considered under the "wetlands" Army Corps of Engincers legal definition, an area must possess three characteristics: hydrophytic vegetation, hydric soils, and wetland hydrology. 